\title{
Quantification of River Nile/Quaternary aquifer exchanges via riverbank filtration by hydrochemical and biological indicators, Assiut, Egypt
}

\author{
Fathy Abdalla ${ }^{1,2, *}$ and Mohamed Shamrukh ${ }^{3}$ \\ ${ }^{1}$ King Saud University, Riyadh, Saudi Arabia. \\ ${ }^{2}$ Geology Department, South Valley University, Qena, Egypt. \\ ${ }^{3}$ Civil Engineering Department, Minia University, Minia, Egypt. \\ *Corresponding author. e-mail: fabdalla@ksu.edu.sa
}

This study approach seeks to characterize the hydraulic interactions between the Nile and the Quaternary aquifer via riverbank filtration (RBF) in Abu Tieg area, Assuit Governorate. The substantial removal/reduction of the most problematic substances during percolation of Nile water into abstraction wells was investigated using physico-chemical and biological indicators. Four sites with 11 municipal wells (20-750 $\mathrm{m}$ from the Nile) tapping the alluvial aquifer that is fed by the riverbank infiltrate were monitored. Bank-filtrated water was compared with those of the Nile and groundwater. Results showed that infiltrated Nile water ratio into the wells ranged from 39 to $80 \%$ reflecting the effect of distance from the Nile. Removal efficiency of total algal, total and faecal coliforms in bank-filtered water was $99.9 \%$, while turbidity removal ranged from 93 to $98 \%$. Fe, Mn and $\mathrm{Zn}$ in the bank-filtered water were relatively higher than those in the Nile, but were still under the allowable standards except those of Mn. LSI and WQI for the bank-filtered water indicated that the water was ranked as non-corrosive and of excellent quality. Comparison of physico-chemical and microbiological characteristics of the bank-filtered water with those of the Nile and groundwater showed the high efficiency of RBF as a treatment technology with minimal cost compared to conventional methods.

\section{Introduction}

The importance of surface water/groundwater exchanges via RBF which is related to the supplying of potable water became a valuable tool for the long-term management of water resources. $\mathrm{RBF}$ is a natural purification process, using alluvial sediments of the lateral shallow aquifers to remove contaminants and microbial loads from surface water for drinking water production. Surface waters bodies (rivers, lakes and canals) are highly exposed to pollution from discharging untreated liquid wastes from industrial, agricultural and domestic activities. Accordingly, various pollutants could be recorded in surface waters. The fate of these substances is controlled to a large extent by filtration, dilution, sorption and biological degradation during subsurface passage through riverbank sediments which is known as RBF (figure 1). Compared with surface water, groundwater is well protected against most types of pollution, recognized as being free of pathogenic organisms and is of relatively regular quality and temperature. Nevertheless, underground sewage lines and untreated sewage discharges may deteriorate the shallow groundwater quality especially in areas that are not

Keywords. Riverbank filtration; biological indicators; turbidity; water quality index; Nile; groundwater. 
connected to the public sewerage system. Disposal of domestic wastewater from sewage that may contain many types of disease-causing organisms into the subsurface may introduce contaminants especially microbes, nitrate and trace elements into the shallow aquifers.

Pathogens are of serious concern because excessive amounts of faecal coliform bacteria such as Escherichia coli (E. coli) in sewage are common indicators of water contamination with disease causing pathogens in human (diarrhea, abdominal cramps and vomiting due to salmonella, cholera). The presence of E. coli as a subgroup of fecal

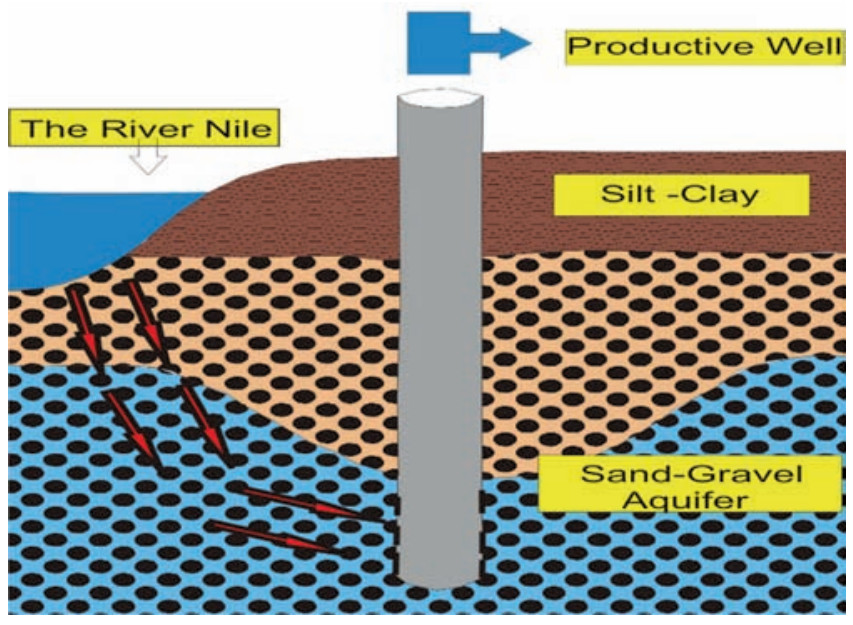

Figure 1. Definition scheme for Nile and groundwater interaction via $\mathrm{RBF}$.
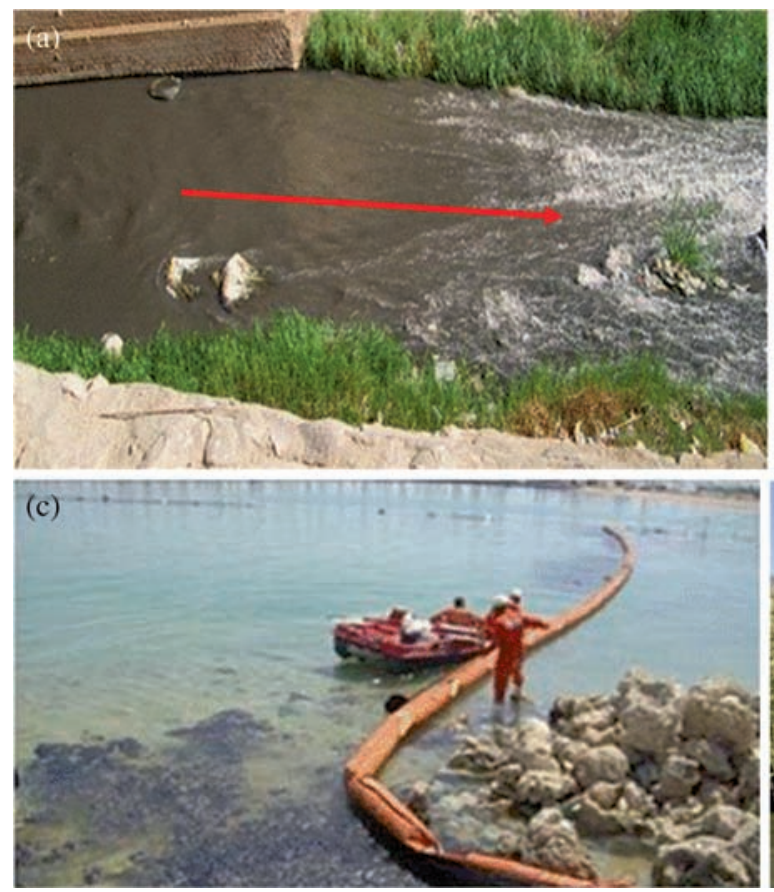

coliform in drinking water is a strong indication of recent sewage or animal waste contamination. Coliform bacteria is common in the environment and is generally not harmful but indicates that the water may be contaminated with germs (disease-causing organisms). The use of indicator bacteria such as total bacterial count, total and faecal coliforms is of great importance in water quality definition and health risk assessment (Fleisher et al. 1998; Macler and Merkel 2000; Giannoulis et al. 2005). Bacterial contamination in water resources is probably from infiltration of domestic or wild animal fecal waste, effluent from leaking septic systems or raw sewage discharges. In case of turbid water, turbidity particles interfere with disinfection and form shields for viruses and bacteria providing a medium for microbial survival and growth (Avvannavar and Shrihari 2008). The presence of algae in water bodies may affect the quality of drinking water because of their production of odor and color- and taste-causing compounds. They also may interfere with some disinfectant substances used in treatment plant (Shehata et al. 2008). Nitrate as a representative of agricultural contaminant is known as a highly mobile and stable anion in shallow aerobic groundwater. Thus, it is a contaminant of concern with respect to drinking water quality and surface water eutrophication (Robertson et al. 1991; Wilhelm et al. 1994b; Valiela et al. 1997).

In Egypt from Aswan to Cairo, the Nile receives wastewater discharge from more than 124 point sources (figure 2) along the Nile banks, 67 points are
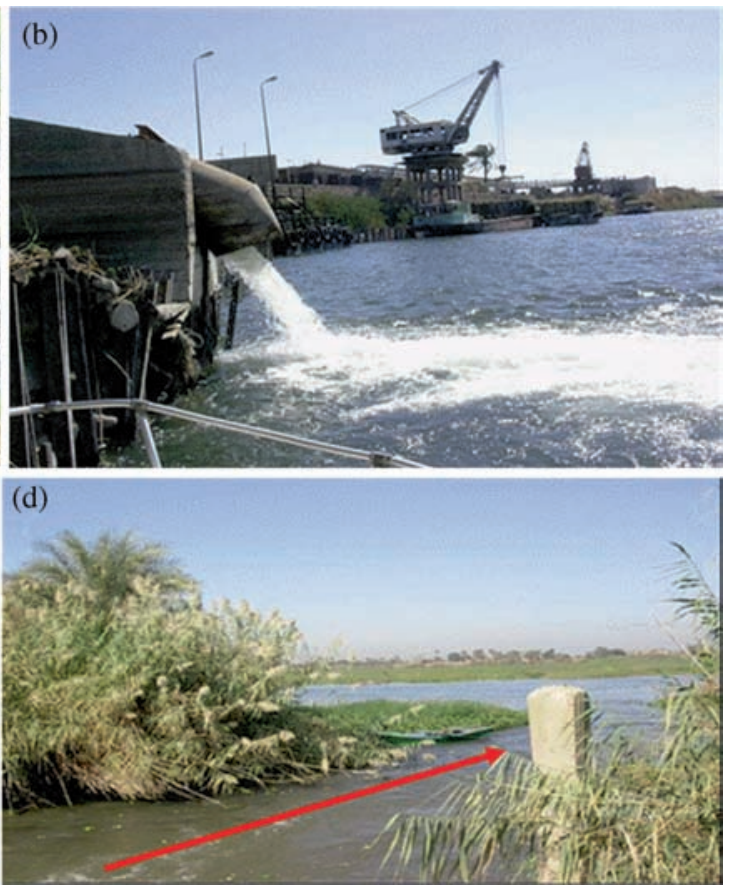

Figure 2. Main sources of contamination to the River Nile; (a) Kima fertilizer factory, Aswan, (b) Qus sugar factory, Qena, (c) Oil tanker accident, Aswan, 2010, (d) Agricultural drainage discharge, Aboshosha village. 
agricultural, while the rest are industrial drains. These discharge more than $50,00,000 \mathrm{~m}^{3}$ of water that contains untreated or partially treated wastewater into Nile (Abdalla and Shamrukh 2011). Accordingly, various pollutants might be recorded in the river water. Source water with high dissolved organic carbon (DOC) and bromide concentrations requires special and additional treatment steps. Organic contaminants may move into the Nile water from the surrounding cultivated lands, wastewater discharge from villages and towns. In the water treatment process, all chemical disinfectants are poisons to some extent, and the most common are oxidizers such as ozone and chlorine. In Egypt, chlorine $\left(\mathrm{Cl}_{2}\right)$ is the most important disinfectant used against waterborne diseases, while organic compounds are the most common oxidizable contaminants. The World Health Organization (WHO) (2008) has established a guideline value of $5 \mathrm{mg} / \mathrm{l}$ for chlorine in drinking water. Disinfectant by-products (DBPs) are chemicals that result from the reaction of chlorine as a water disinfectant with organic substances in raw water. Trihalomethanes (THMs) is the major class of halogenated DBPs found in nearly every chlorinated public water supply (IARC 1991). Chlorine combines with naturally-occurring bromide in the water, forming bromine. Like $\mathrm{Cl}_{2}$, bromine can react with naturally-occurring organic matter in water (total organic carbon - TOC) to form brominated organic byproducts (THMs). Complex mixtures of DBPs are formed when natural source water is disinfected with oxidants, such as chlorine and recognized their carcinogenic potential (Pressman et al. 2010).

Some epidemiological investigations have found that people who drink chlorinated surface water have a higher risk of developing cancer of the bladder, rectum and colon (Richardson et al. 2007), and adverse reproductive outcomes, including spontaneous abortion and low birth weight (Nieuwenhuijsen et al. 2009; Ozoko 2015). The discharge of untreated wastewater, agricultural runoff and raw sewage into the Nile can lead to the deterioration of groundwater in the adjacent Quaternary aquifer. Accordingly, direct extraction of Nile water as drinking water might be replaced by natural or artificial subsoil passage of Nile water via $R B F$ process. This is because of its anticipated efficiency in removing pathogenic organisms, turbidity, temperature deviations as well as many other pollutants from the infiltrating of polluted river water. $\mathrm{RBF}$ is a natural purification process, using aquifer sediments in removing contaminants and pathogenic organisms from polluted surface water for drinking water production (Kim et al. 2003). This purification method is relatively simple, low-cost and makes subsequent disinfection treatment more safer. Worldwide, RBF has been recognized (Doussan et al. 1997; Schmidt et al. 2003), it is widely applied in many European countries, especially Netherlands, Germany, France and the United States (van der Kooij et al. 1985; Stuyfzand 1998; Kuehn and Mueller 2000; Ray et al. 2002; Kim et al. 2003). In Egypt, pictures on temple walls dating back to $15^{\text {th }}$ century BC showed that the Egyptians used BF to improve the Nile water quality (when the Nile water turned into blood colour due to algal bloom) by digging around the Nile to drink (Deininger et al. 2002).

In spite of these advantages, the RBF system has some limitations; the most common are plugging/clogging of the bank filter interface which cause gradual reduction in production capacity and remobilization of heavy metals (i.e., Fe and $\mathrm{Mn}$ ). Although, iron and manganese are not particularly toxic, they can impair the taste of water and cause problems in pipelines, water heaters, laundry and water softeners if they are present in concentrations greater than the standards. The presence of heavy metals such as lead, zinc, cadmium, copper and chromium in drinking water are receiving increased attention from water treatment authorities due to their poisoning effects on human. Their known fatal effects include adverse impacts on mental and central nervous functions. The long-term exposure of these metals result in physical and neurological degenerative processes that cause Alzheimer's disease (ATSDR 1992; Mohod and Dhote 2013).

In the past 10 years, few studies have been carried out in certain locations along the Nile valley; they evaluate and describe the ability of RBF to remove/reduce water contaminants particularly turbidity and micro-organisms before reaching the production well. These include Abdel-Lah and Shamrukh (2006); Shamrukh and Abdel-Wahab (2008, 2009, 2011); Abdalla and Shamrukh (2011); and Bartak et al. (2014), these were helpful to some extent to understand the process of RBF. In this method, abstraction wells are installed within riverbank sediments to collect Nile water that filters during ground passage in riverbank deposits, which means almost pure bank-filtered water was extracted (figure 1). Aquifer particle properties especially grain size and distribution, the riverbank sediment, the infiltration velocity, and the residence time affect the effectiveness of riverbank filtration or the quality of bank-filtrated water that vary greatly among sites. Elimination rates depend upon residence time (the travel time of polluted raw-water from the Nile to the wells), length of the flow path (distance between river and wells), prevailing redox conditions and the river water quality near the abstraction well. The effects of the well depth and the screen length by which the method is more effective are not well understood at 
the present time, therefore, further researches are required.

This paper investigates the interaction between the Nile and the Quaternary aquifer that are hydraulically connected; discusses the potentiality of the RBF as protection measure with high degree of removal efficiency for the most problematic substances such as particles and micro-organisms. Moreover, travel time of Nile water with pollutants into the production wells, as well as the contribution ratio of Nile water through bank filtration were estimated. Finally, the suitability of bankfiltered water for drinking purposes with the standards set by the Egyptian Higher Committee for Water (EHWC) (2007) and WHO (2008) based on water quality index (WQI) was evaluated.

\section{Examination sites}

The four study sites are located in the vicinity of Abu Tieg City, $20 \mathrm{~km}$ south of Assiut barrage on the west bank of Nile between latitudes $27^{\circ} 02^{\prime} 40^{\prime \prime}-$ $27^{\circ} 07^{\prime} 14^{\prime \prime} \mathrm{N}$ and longitudes $31^{\circ} 20^{\prime} 386^{\prime \prime}-31^{\circ} 21^{\prime} 40^{\prime \prime} \mathrm{E}$ (figure 3 ). The area is known for its dry climatic conditions with mean annual temperature of $37^{\circ} \mathrm{C}$ and annual rainfall of around $7 \mathrm{~mm}$. An abnormal rainfall event in the area occurs occasionally over a short duration and may result in dangerous flash flood (Korany et al. 2013). These monitored sites form part of an important well field along the River Nile. Abu Tieg wellfield is $20 \mathrm{~km}$ south of Assuit; it contains five vertical municipal wells tapping the alluvial aquifer each $160 \mathrm{~m}$ depth (50 m screen) and 20-80 $\mathrm{m}$ from the Nile (figure 3). Baqure wells are $3 \mathrm{~km}$ north of Abu Tieg and $1.75 \mathrm{~km}$ from the Nile, $90 \mathrm{~m}$ deep and $25 \mathrm{~m}$ screen. New El Matia wells are $10 \mathrm{~km}$ north of Abu Tieg and $50 \mathrm{~m}$ from the Nile, $90 \mathrm{~m}$ deep and $25 \mathrm{~m}$ screen. Old El Matia are $700 \mathrm{~m}$ from the Nile, $90 \mathrm{~m}$ deep and $25 \mathrm{~m}$ screen. The choice of these test sites takes into consideration of several important factors: the existence of hydraulic connection between the Nile and the aquifer where the riverbed penetrated the bottom of the clay overbank; the main recharge component of the aquifer is the water infiltrate from the Nile due to increasing of water head in the upstream part of Assiut barrage; the presence of a number of production wells penetrating the Pleistocene layer, and the existence of previous studies (Shamrukh and Abdel-Wahab 2008, 2011; Abdalla and Shamrukh 2011). Two previously reported groundwater wells, $7.5 \mathrm{~km}$ away from the Nile River were chosen as reference samples from Korany et al. (2013). Thus, the area could be considered as one of the most favourable area for RBF application. According to Bartak et al. (2014), to receive a higher portion of
Nile water into the abstraction wells, the depth of the wells should not be $>42 \mathrm{~m}$ and the standard 6 $\mathrm{m}$ screen could be placed between 12 and $24 \mathrm{~m}$ or 18 and $30 \mathrm{~m}$ below the ground surface due to the thickness of the clay overbank.

\subsection{Geological and hydrogeological setting}

The study sites are considered as part of the Nile Valley and are covered by sedimentary deposits belonging to the age of Quaternary through Late Cretaceous with an average thickness up to 1500 m (Said 1981; Ibrahim et al. 1995). Quaternary sediments compress young alluvial sediments (Holocene silt) and old alluvial sediments (Pleistocene sand). The Quaternary and Late Tertiary sand and gravel beds with clay lenses intercalation form the Nile Valley aquifer in Upper Egypt, which is underlined by Pliocene clays as aquiclude layer. The surface water system in the study sites includes the River Nile besides the main irrigation canals (El Ibrahimia and Nag Hammadi). Groundwater aquifers from top to bottom are represented by the Pleistocene, the Plio-Pleistocene and the Lower Eocene limestone aquifers (Abdalla and Shamrukh 2011; Korany et al. 2013). The Quaternary aquifer (our target) extends in the Nile Valley to the east and west of the Nile and within the main desert channels. It is mainly formed of sands and gravels at the base, and semi-permeable clay-silt layers at the top. The thickness of this aquifer as well as its width differs from one locality to another. In Abu Tieg area, its thickness varies from $>200 \mathrm{~m}$ at the middle part of the flood plain to $<30 \mathrm{~m}$ near the edges of the plateau on both sides of the river. The depth to water table varies from 3 to $20 \mathrm{~m}$ and is deeper at Wadi El Assiuti where the depths vary from $26 \mathrm{~m}$ near the Nile Valley to more than $80 \mathrm{~m}$ towards the east (Korany et al. 2013). The hydraulic conductivity of the Pleistocene layer ranges from 60 to $100 \mathrm{~m} /$ day, where transmissivity ranges from 2000 to $6000 \mathrm{~m}^{2} /$ day, these high values guarantee a good hydraulic connection between the Nile and the Quaternary aquifer.

The main component of recharge of the aquifer at the study sites are seepage from the River Nile and applied irrigation, subsurface drainage from the irrigated lands and the expected upward leakage from the deep aquifers through fracture planes. Discharge components include groundwater pumping from wells and capillary upward flow from a shallow water table owing to evapotranspiration. The general groundwater flow direction is from south to north coinciding with the regional slope of the Nile Valley, where groundwater level decreases gently northwards, it is in the range of $+85 \mathrm{~m}$ at 


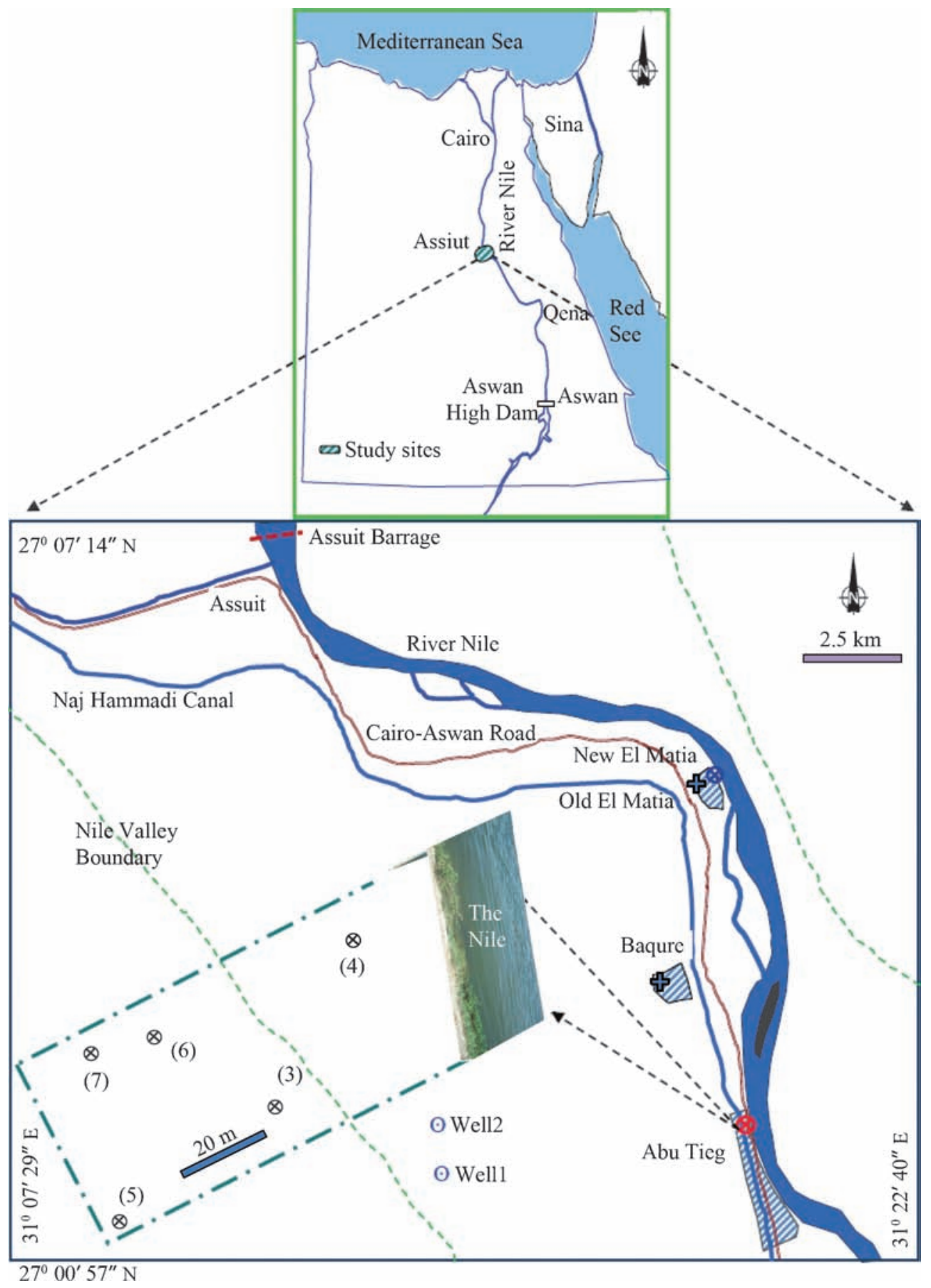

Figure 3. Location map shows Abu Tiej, Baqure and El Matia test sites with Abu Tiej RBF wells location.

Aswan and about $+45 \mathrm{~m}$ at Assiut (Farrag 2005). Lateral groundwater flow occurs from the River Nile to the aquifer is quite proved between Abu Tieg and Assiut barrage (figure 3), accordingly the main recharge source of aquifer in the test sites is the water seepage from the Nile, although the Nile River acts as a drain for the Quaternary aquifer (Mousa et al. 1994; El Miligy 2004; Abdalla and Shamrukh 2011; Dawoud and Ismail 2013). Based on El Miligy (2004) investigation, the potentiometric head of the aquifer in the study area slopes gradually from south to north. The highest contour lines $(+50 \mathrm{~m}$ asl $)$ are at Abu Tieg and the lowest $(+43 \mathrm{~m}$ asl $)$ at Dyirout area $75 \mathrm{~km}$ north of $\mathrm{Abu}$ Tieg.

\section{Materials and methods}

To evaluate the efficacy of RBF plant in the study sites, 12 water samples from the four sites located at different distances from riverbank and the Nile 
were collected (five samples from Abu Tiej, four samples from El Matia, two samples from Baqure and one surface water sample from the Nile). Sampling point names and locations were given in figure 3 and table 1. During the field work, one additional water sample from each sampling point was collected and analyzed in Assuit Holding Company for drinking water and wastewater. To assess the variability of groundwater data resulting from samples collection and laboratory analysis, all samples were collected in duplicate and analyzed in replicate. Assessment of the quality-control data resulted $<5 \%$ of the error from the different replicates. In order to preserve the samples for cation and trace element measurements, samples were acidified using $\mathrm{HNO}_{3}$. Water samples were analyzed to determine the physico-chemical and microbiological quality parameters. Turbidity, total hardness $(\mathrm{TH})$, alkalinity, total dissolved solids (TDS), temperature (T), pH and electrical conductivity (EC) of the collected water samples were measured immediately at the sampling sites. The water samples were analyzed for other major water quality parameters such as sodium, calcium, magnesium, sulphate, chloride, bicarbonate, nitrate, iron, manganese, zinc, copper, nickel, lead, chromium, cadmium, total and faecal coliforms and total algal. Analyses were carried out according to the Egyptian standards and the procedures of the American Public Health Association (APHA 1998). The concentrations of cations were measured using atom adsorption spectrometry (Analytik Jena AAS NOvAA 400G). The selected trace metals were determined by the application of graphite furnace AAS, where ion chromatography (Dionex
DX 120) was used for anion determination. The chemical analyses were done at the geochemical laboratory of Berlin University of Technology, Germany, where the microbiological measurements were carried out at the central laboratory of Health Ministry in Cairo.

$\mathrm{TH}$ was calcualted as $\mathrm{CaCO}_{3} \mathrm{mg} / \mathrm{l}$ according to Todd (1980) as follows:

$$
\mathrm{TH}=2.5 \mathrm{Ca}(\mathrm{mg} / \mathrm{l})+4.1 \mathrm{Mg}(\mathrm{mg} / \mathrm{l}) .
$$

Calculation of the travel time from Nile to the abstracted wells for RBF at Abu Tieg site using Darcy's velocity equation that can be expressed (in $\mathrm{m} / \mathrm{d}$ ) as follows:

$$
V_{f}=K_{f} \cdot I .
$$

Equation (2) can be rewritten in the following form to give average or seepage velocity (Darcy's velocity divided by the effective porosity, $\left.n_{e}\right)$ :

$$
V_{a}=\frac{V_{f}}{n_{e}}=\left(\frac{K_{f}}{n_{e}}\right) I
$$

where $n_{e}$ assumed to be $0.18, I$ is the hydraulic gradient assumed to be 0.01 and $K_{f}$ is the hydraulic conductivity $(60 \mathrm{~m} /$ day $)$.

The effectiveness and performance of the RBF system:

The proportions of Nile water that infiltrated the bank (bank-filtered water) in the test sites can be estimated based on the following equation (Shamrukh and Abdel-Wahab 2008):

$$
B=\frac{C p i-C g w}{C r w-C g w} \times 100
$$

\begin{tabular}{|c|c|c|c|c|c|c|c|c|c|c|c|c|c|c|c|}
\hline & Distance & Temp & & TDS & $\mathrm{TH}$ & K & $\mathrm{Na}$ & $\mathrm{Mg}$ & $\mathrm{Ca}$ & $\mathrm{Cl}$ & $\mathrm{NO}_{3}$ & $\mathrm{SO}_{4}$ & $\mathrm{HCO}_{3}$ & \multirow{2}{*}{$\begin{array}{c}\text { Alkalinity } \\
(\mathrm{mg} / \mathrm{l})\end{array}$} & \multirow{2}{*}{ WQI } \\
\hline Sample & $(\mathrm{km})$ & $\left({ }^{\circ} \mathrm{C}\right)$ & $\mathrm{pH}$ & $(\mathrm{mg} / \mathrm{l})$ & $(\mathrm{mg} / \mathrm{l})$ & $(\mathrm{mg} / \mathrm{l})$ & $(\mathrm{mg} / \mathrm{l})$ & $(\mathrm{mg} / \mathrm{l})$ & $(\mathrm{mg} / \mathrm{l})$ & $(\mathrm{mg} / \mathrm{l})$ & $(\mathrm{mg} / \mathrm{l})$ & $(\mathrm{mg} / \mathrm{l})$ & $(\mathrm{mg} / \mathrm{l})$ & & \\
\hline AbuTiej7 & $\sim 0.08$ & 16.8 & 7.6 & 245 & 190.8 & 2.3 & 22.8 & 22.7 & 39.1 & 10.5 & 1.0 & 10.7 & 302.2 & 193 & 21.5 \\
\hline AbuTiej3 & $\sim 0.04$ & 17.3 & 7.8 & 248 & 174.9 & 3.5 & 21.5 & 17.3 & 41.6 & 13.6 & 0.8 & 14.0 & 316.1 & 213 & 21.3 \\
\hline AbuTiej4 & $\sim 0.02$ & 17.5 & 8.2 & 238 & 192.4 & 2.5 & 20.9 & 18.4 & 46.8 & 7.3 & 0.4 & 10.1 & 318.3 & 180 & 20.6 \\
\hline AbuTiej5 & $\sim 0.08$ & 16.9 & 7.8 & 227 & 170.9 & 2.1 & 20.8 & 17.8 & 39.2 & 13.1 & 0.3 & 11.9 & 288.4 & 175 & 13.0 \\
\hline AbuTiej6 & $\sim 0.05$ & 17.8 & 7.7 & 248 & 171.5 & 2.5 & 19.8 & 16.1 & 42.2 & 16.8 & 0.4 & 13.3 & 281.6 & 188 & 24.7 \\
\hline Baqure1 & $\sim 1.75$ & 18.2 & 8.2 & 280 & 177.0 & 2.7 & 27.3 & 16.1 & 44.4 & 23.5 & 0.9 & 17.9 & 366.1 & 223 & 35.9 \\
\hline Baqure2 & $\sim 1.75$ & 18.5 & 7.8 & 420 & 257.8 & 4.0 & 68.2 & 24.1 & 63.6 & 41.9 & 0.5 & 32.6 & 555.3 & 311 & 40.3 \\
\hline New El Matia1 & $\sim 0.05$ & 17.8 & 7.7 & 325 & 309.1 & 3.9 & 92.7 & 29.3 & 75.6 & 55.9 & 0.7 & 37.7 & 501.8 & 300 & 30.7 \\
\hline New El Matia2 & $\sim 0.5$ & 17.3 & 8.0 & 388 & 309.1 & 3.9 & 92.7 & 29.3 & 75.6 & 63.9 & 1.1 & 37.7 & 478.8 & 321 & 31.5 \\
\hline Old El Matia1 & $\sim 0.75$ & 17.9 & 7.6 & 550 & 251.4 & 3.1 & 80.6 & 25.3 & 59.1 & 38.6 & 3.5 & 39.6 & 610.2 & 332 & 35.5 \\
\hline Old El Matia2 & $\sim 0.75$ & 18.2 & 7.3 & 621 & 229.8 & 4.1 & 77.3 & 18.2 & 62.1 & 67.1 & 4.2 & 42.1 & 587.1 & 341 & 35.9 \\
\hline \multicolumn{16}{|c|}{ Reference } \\
\hline Well1* & $\sim 7.5$ & na & 7.8 & 570 & 404.6 & 15.6 & 91.8 & 40.2 & 47.8 & 95.7 & na & 105 & 298.7 & na & 56.5 \\
\hline Well2* & $\sim 7.5$ & na & 8.2 & 678 & 270.1 & 9.7 & 143 & 48.1 & 28.9 & 86.5 & na & 163 & 343.6 & na & 64.6 \\
\hline The Nile & & 27 & 8.1 & 186 & 118.7 & 3.4 & 22.2 & 10.3 & 30.6 & 10.5 & 0.7 & 10.7 & 200.1 & 135 & $>100$ \\
\hline
\end{tabular}

Table 1. Hydrochemical analyses of the data of investigated water samples in $\mathrm{mg} / \mathrm{l}$ and wells distance from the Nile bank in the test sites.

*Data derived from Korany et al. (2013); na: not available. 
where $B$ is the bank infiltration ratio in the production well (\%), $C p i$ is the conservative chemical concentration in the production well, $\mathrm{Crw}$ is the conservative chemical concentration in the river water and $C g w$ is the conservative chemical concentration in the groundwater.

In evaluating the corrosion/dissolution potentials of study water samples, Langelier saturation index (LSI) was calculated to evaluate the chemical stability of the bank-filtrated water. LSI expresses the tendency of water towards precipitation or dissolution, it is calculated using PHREEQC for Windows at formation temperature with regard to calcite as the main carbonate mineral. The $S I$ of a particular mineral could be defined as:

$$
S I=\log (I A P / K),
$$

where $I A P$ is the ion activity product and $K$ is the equilibrium constant.

The water quality index (WQI) was evaluated according to Farrag (2005); Akoteyon et al. (2011); Balan et al. (2012); and Seth et al. (2014). The simplified model for WQI can vary from zero (excellent) to 100 (very poor). The quality rating $q_{i}$ is calculated as follows:

$$
q_{i}=\left(V_{i} / S_{i}\right) \times 100
$$

where $q_{i}, V_{i}$ and $S_{i}$ are the quality rating, measured value and the slandered value of the $i^{\text {th }}$ parameter respectively. The average value of WQI for the examined samples is given by:

$$
Q=\frac{\sum_{i=1}^{n} q_{i}}{n}
$$

Nine water quality parameters were considered $(n=9)$ namely, turbidity, TDS, TH, $\mathrm{Na}, \mathrm{SO}_{4}, \mathrm{NO}_{3}$, $\mathrm{Fe}$, total and faecal coliforms bacteria.

When WQI equals 100, it means that the water is saturated regarding the measured factors, compared with their standards. If it is $<100$, it means that the water is desirable and suitable for drinking and domestic purposes. When WQI $>100$ means that the water is oversaturated or polluted and it is not suitable for drinking and domestic purposes.

\section{Results and discussion}

\subsection{Nile-groundwater interaction}

To make optimum use of Nile water, a number of regulating barrages for control and diversion of the river flow have been constructed, one of these barrages is the Assiut barrage. Due to direct hydraulic conductivity between the Nile and Quaternary aquifer in the Nile Valley, increasing the Nile level upstream of the barrages will raise the groundwater level. Considering the Nile and groundwater level in the test sites (figure 4), it can be inferred that in the upstream part of the barrage, the river water will recharge the aquifer (as the groundwater level is lower due to pumping). The amount of flowing water from the river to the aquifer depends on the difference in water head between the aquifer and the Nile, as well as the hydraulic conductance of the base layer sediments of the river. The flow rate of Nile raw-water into the aquifer due to the high

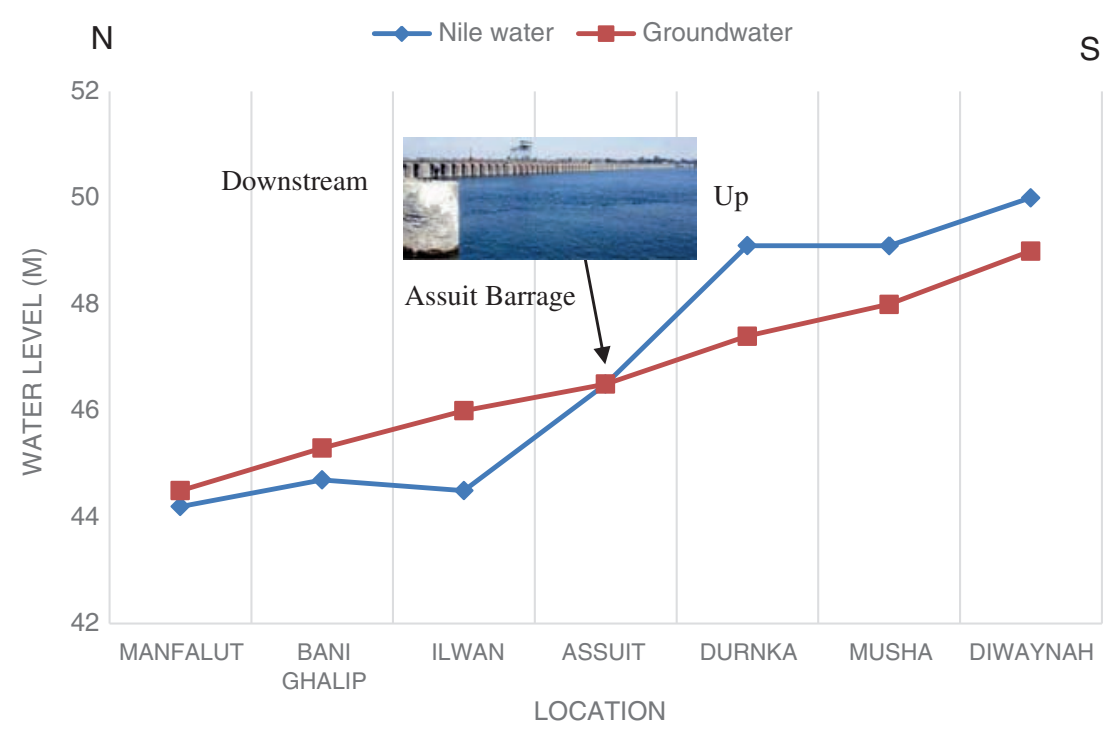

Figure 4. Relationship of groundwater and Nile water in upstream and downstream parts of Assiut barrage (water level data derived from El Miligy 2004). 
water level in the upstream part of Assiut barrage compared with groundwater head of the aquifer was $1080 \mathrm{~m}^{3} /$ day (El Miligy 2004).

\subsection{Effectiveness and performance of $R B F$}

The interaction between the Nile water and groundwater in the surrounding aquifer can be explained through the ratio of bank filtrate water in the abstracted wells. The hydraulic interaction between the Nile and Quaternary aquifer depends on the hydrologic conditions and the location of the abstracted wells from the river. The estimated seepage velocity of Nile water towards the test wells using equation (3) is $3.4 \mathrm{~m} / \mathrm{d}$. That means the travel time of Nile water to the nearest test well at Abu Tieg site $(20 \mathrm{~m}$ from the Nile) is about 6 days and 15 days for the farthest well $(70 \mathrm{~m}$ from the Nile). As expected, due to enough residence time ( $\sim 1$ to 2 weeks), removal efficiency of the suspended particles and pathogen removal in the simulated RBF system are significant and sufficient, these will result in lower coagulant dosages and less sludge production in the treatment plant. The three major groups of concern are Protozoa, bacteria and virus with different sizes $1-12,0.5-3 \mu \mathrm{m}$ and 20-30 nm, respectively. RBF cannot guarantee their complete removal, but with increasing travel time (weeks), it can effectively reduce them.

To evaluate the effectiveness and performance of the RB system, the proportions of surface water that infiltrated the bank in the Abu Tieg, El Matia and Baqure sites were calculated using the TDS and chloride concentration as tracer to identify interaction between Nile and groundwater for riverbank filtrate. The first initial water is Abu Tieg2 sample which represents the conservative chemical concentration in the production well, the second initial water is the sample from River Nile and the third initial water are two groundwater samples (well-1 and well-2) about $7 \mathrm{~km}$ from the Nile west of Abu Tieg (figure 3 and table 1). The results revealed that Abu Tieg site receives bank filtrate water up to $80 \%$, whereas new El Matia site receives up to $75 \%$. Old El Matia and Baqure sites receive up to $39 \%$ of Nile water, and that reflects the effect of the distance between Nile and the production wells. Thus, flow distance ranging from 20 to $70 \mathrm{~m}$ between the riverbank and the production well was found to be sufficient to receive high portion of Nile water and reduce/remove the pathogens and suspended load in the production water. Based on these results and to ensure sufficient removal of bacteria, algae and suspended load, construction of future RBF sites along the Nile is proposed between 20 and $70 \mathrm{~m}$ from the Nile bank.

\subsection{Variation of hydrochemical properties}

The quality of Nile and bank-filtered water was assessed based on the results of physico-chemical and bacteriologic characteristics (tables 1 and 2) in accordance with the drinking water regulations set by the EHCW (2007) and WHO (2008).

\subsubsection{Quality of Nile water}

Nile water quality in the study sites was monitored, the results showed that water temperature was $27^{\circ} \mathrm{C}$ and $\mathrm{pH}$ value was slightly alkaline (8.1). $\mathrm{pH}$ has profound effects on water quality affecting the ability of bacteria which require slightly acidic conditions to degrade toxic substances to less harmful forms (Adeogun 2012). The $\mathrm{pH}$ value is within the permissible limit (6.5-8.5) prescribed for drinking water by the EHCW guidelines and WHO standards. Turbidity as a measure of cloudiness in water caused by various mixtures of organic and inorganic materials such as colloidal organic matter, clay, silt, and other organisms. Turbidity has no health effects, but it may indicate the presence

Table 2. Concentrations of trace constituents, TOC, turbidity, SI and microbiological water quality parameters in the test sites.

\begin{tabular}{|c|c|c|c|c|c|c|c|c|c|}
\hline Sample & $\begin{array}{l}\text { TOC } \\
(\mathrm{mg} / \mathrm{l})\end{array}$ & $\begin{array}{c}\mathrm{Fe} \\
(\mathrm{mg} / \mathrm{l})\end{array}$ & $\begin{array}{c}\mathrm{Mn} \\
(\mathrm{mg} / \mathrm{l})\end{array}$ & $\begin{array}{c}\mathrm{Zn} \\
(\mathrm{mg} / \mathrm{l})\end{array}$ & $\begin{array}{l}\text { Turbidity } \\
\text { (NTU) }\end{array}$ & $\begin{array}{c}\text { SI } \\
\text { calcite }\end{array}$ & $\begin{array}{l}\text { Total coliform } \\
(\mathrm{cfu} / 100 / \mathrm{ml})\end{array}$ & $\begin{array}{l}\text { Faecal coliform } \\
(\mathrm{cfu} / 100 / \mathrm{ml})\end{array}$ & $\begin{array}{c}\text { Total algae } \\
\text { (unit/ml) }\end{array}$ \\
\hline AbuTiej7 & 3.09 & 0.12 & 0.21 & 0.03 & 0.71 & 0.12 & $<1$ & $<1$ & $<1$ \\
\hline AbuTiej3 & 3.10 & 0.14 & 0.34 & 0.01 & 0.65 & 0.48 & $<1$ & $<1$ & $<1$ \\
\hline AbuTiej4 & 2.45 & 0.19 & 0.25 & 0.03 & 0.42 & 0.64 & $<1$ & $<1$ & $<1$ \\
\hline AbuTiej5 & 2.32 & 0.06 & 0.09 & 0.02 & 0.22 & 0.40 & $<1$ & $<1$ & $<1$ \\
\hline AbuTiej6 & 2.26 & 0.24 & 0.17 & 0.03 & 0.65 & 0.046 & $<1$ & $<1$ & $<1$ \\
\hline Baqure1 & 1.87 & 0.24 & 0.25 & 0.08 & 0.23 & 0.68 & na & na & na \\
\hline Baqure2 & 4.21 & 0.30 & 0.45 & 0.03 & 0.21 & 0.59 & $<1$ & $<1$ & $<1$ \\
\hline New El Matia1 & 2.59 & 0.23 & 0.37 & 0.05 & 0.4 & 0.53 & $<1$ & $<1$ & $<1$ \\
\hline Old El Matia1 & 1.84 & 0.03 & 0.10 & 0.08 & 0.4 & 0.35 & na & na & na \\
\hline The Nile & 4.43 & 0.08 & 0.01 & 0.01 & 11 & 0.38 & 950 & 325 & 1100 \\
\hline
\end{tabular}

Note. na: not available. 
of suspended particles and disease-causing organisms such as bacteria, viruses, and parasites. Measured nephelometric turbidity unit (NTU) of the Nile water was 11 (table 2), that is highly above the permissible limit for drinking of 1.0 NTU. This high value of turbidity may result from settling of suspended particulates in the upstream part of the high dam, soil bank erosion, waste discharge, and algal growth. Consumption of turbid water causes many gastroenteritis problems (Morris et al. 1996), where turbidity may interfere with disinfection substances providing a suitable medium for bacterial and microbial growth, especially if the Nile receives a high load of sewage. In addition, high turbid water shortens the filter runs and many pathogenic organisms may be encased in the particles and protected from the disinfectant (Avvannavar and Shrihari 2008).

TDS and TH values of the Nile water were 122 and $186 \mathrm{mg} / \mathrm{l}$, respectively, the values were far below the permissible limits of $500 \mathrm{mg} / \mathrm{l}$. Iron, manganese and zinc were detected in RBF wells and the Nile water. However, copper, nickel, lead, chromium and cadmium were also analyzed, but their concentrations in all water samples were lower than the limits of determination $(0.005 \mathrm{mg} / \mathrm{l})$. The concentrations of iron, manganese and zinc in Nile water were $0.08,0.01$ and $0.01 \mathrm{mg} / \mathrm{l}$, respectively, which are below the acceptable limits of WHO (0.3, 0.4 and $5 \mathrm{mg} / \mathrm{l}$ for $\mathrm{Fe}, \mathrm{Mn}$ and $\mathrm{Zn}$, respectively). Results have also shown that nitrate concentration in Nile water was found within permissible limits according to EHCW and WHO (table 1). Results of the microbiological analysis showed that the total and faecal coliforms $(\mathrm{cfu} / 100 \mathrm{ml})$ as well as total algal in the Nile water have elevated values that are higher than normal occurring (figure 5). These were above the EHCW and WHO standards which require that drinking water supplies must be free from microorganisms or counts were less than 1 colony forming unit per $100 \mathrm{ml}$ water $(<1$ $\mathrm{CFU} / 100 \mathrm{ml}$ ). Higher bacterial counts clearly indicate that the Nile water is polluted by sewage faecal contamination. The presence of $E$. coli in water bodies indicates recent fecal contamination. This pollution might be due to agricultural drainage containing raw sewage and wastewater discharges into the Nile. In addition to diseases, presence of microorganisms in drinking water may cause sensory defects in taste, color or odor as well as corrosion of steel pipes.

Similarly, the maximum total organic carbon (TOC) contents recorded in Nile waters $(4.43 \mathrm{mg} / \mathrm{l}$, table 2) is relatively higher than the observed concentrations in bank filtrate. The presence of high concentrations of organic components in the Nile water suggest an additional source of TOC, most probably coming from sewage discharge through agricultural drainage from nearby villages and towns. Chloride and sulphate concentrations in the Nile water were 10.5 and $10.7 \mathrm{mg} / \mathrm{l}$, respectively which are less than the permissible limits recommended by EHCW and WHO.

All analyzed physico-chemical and microbiological water quality parameters in the Nile were within the limits set by (EHCW 2007) and WHO (2008) except for turbidity, E. coli bacteria and total coliform and total algae. The high load of bacteria in the Nile water might be from domestic raw sewage coming from agricultural runoff.

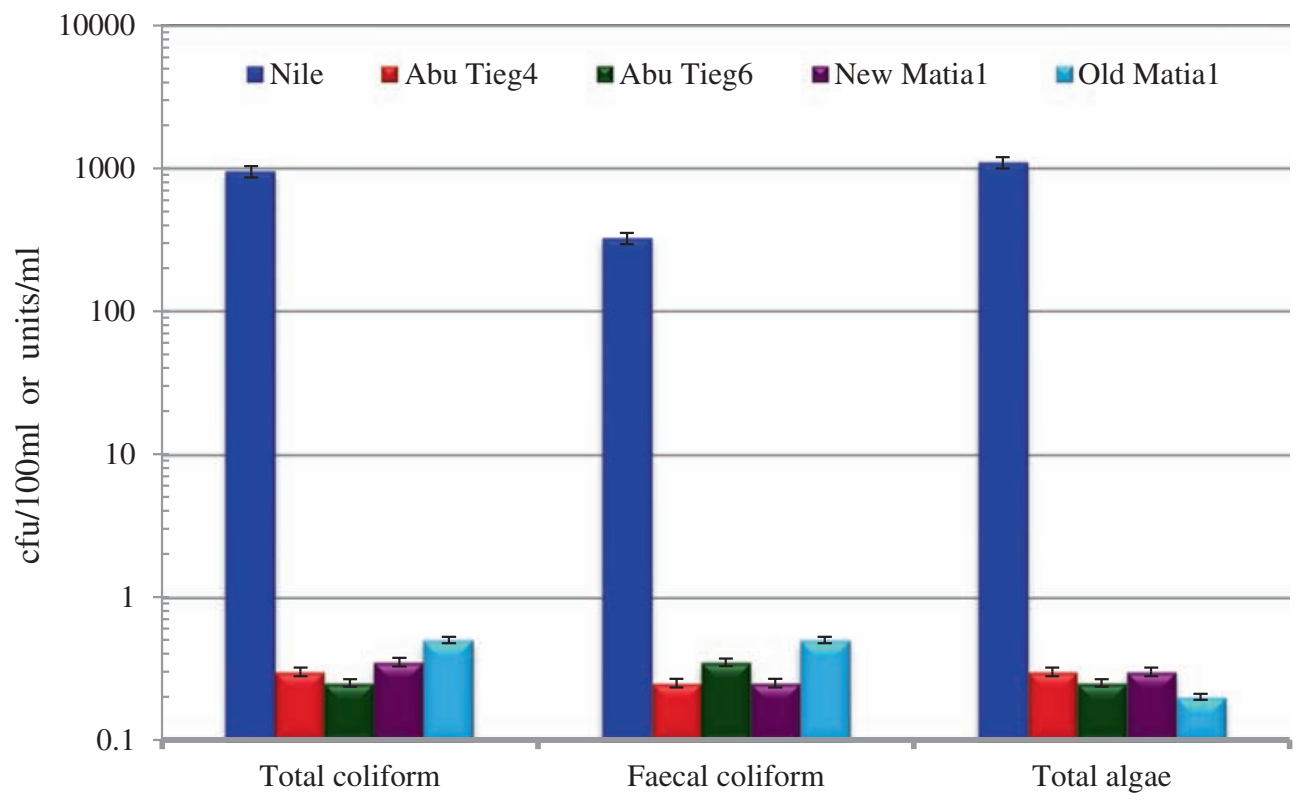

Figure 5. Comparison of total and faecal coliforms as well as total algae in the Nile and bank-filtrated water. 


\subsubsection{Quality of bank-filtered water}

The results showed that the physico-chemical and microbiological water quality parameters of bankfiltered water are different from those of the Nile water. This is likely because of the effects of different physical, chemical and biological removal mechanisms for each constituent (e.g., filtration, sorption, and biotransformation) as well as the expected reducing conditions, particularly, at winter time. The range of temperature of the bankfiltered water was lower than in the Nile water with an average of $16.7^{\circ} \mathrm{C}$. The $\mathrm{pH}$ values of the bank-filtered water wells varied from 7.3 to 8.2 with an average value of 7.8 , indicating slightly alkaline conditions. This alkaline feature may possibly be due to dissolution of base compounds such as calcium bicarbonates. The $\mathrm{pH}$ values of all samples were within the permissible limit (6.5-8.5) prescribed for drinking water by the Egyptian guidelines and WHO standards. The obtained average $\mathrm{pH}$ values did not show much difference from Nile (8.1) and the bank-filtered water with mean values of 7.7, which reflects close association and relationship between them. The turbidity values of the bank-filtered water were less than the permissible limit in all the samples (table 2). This significant reduction in turbidity might be explained by the filtration through riverbank deposits from Nile to the wells.

4.3.2.1 Health-related parameters: The four healthrelated parameters analyzed in the collected bankfiltered water samples were total and faecal coliforms, nitrate and heavy metals.

\section{- Behaviour of biological contaminants}

Results of the microbiological analysis revealed that the total and faecal coliforms as well as total algal in bank-filtered water have nearly disappeared as shown in table 2 and figure 5 . The total and faecal coliforms counts were $<1 \mathrm{CFU} / 100 \mathrm{ml}$ water. The pronounced decrease in faecal coliforms was around $3.5-\log$ removal rate, where total coliform and total algal were about 4-log removal rate (figure 5). Significant reductions of bacteria and algal load in the bank-filtered water (99.9\%) is due to filtration processes through riverbank sediments and the expected reducing conditions.

\section{- Nitrate}

Nitrate average concentrations in bank-filtrate wells ranged between $0.3 \mathrm{mg} / \mathrm{l}$ in Abu Tieg3 and $4.2 \mathrm{mg} / \mathrm{l}$ in old El Matia, and that are below the permissible limits $(50 \mathrm{mg} / \mathrm{l})$. The decrease of nitrate concentrations in the bank-filtered water is possibly due to less infiltration of oxygenated Nile water into the production wells where the Nile received less precipitation in winter time, consequently the Nile water level was low. The relatively elevated concentrations of nitrate in old El Matia well could be attributed to the impact of sewer system in the neighbourhood area where the well field is almost enclosed by near houses and latrines.

\section{- Heavy metals}

Iron, manganese and zinc concentrations in $\mathrm{RBF}$ wells range from $0.03-0.3,0.09-0.45$ and $0.01-$ $0.08 \mathrm{mg} / \mathrm{l}$, respectively (table 2 and figure 6 ). These concentrations are higher than those of the Nile water, but they are still under the permissible limits recommended by EHCW and WHO except those for $\mathrm{Mn}$, where post-treatment is needed. Thus, it indicates pollution hazards encompassing emission of iron, manganese and zinc in drinking waters is due to the remobilization processes and redox reactions. As mentioned before, high values of iron and manganese do not pose any known health risks, but can cause an unpleasant metallic taste to the water and staining of laundry.

4.3.2.2 Non-health related parameters: Three nonhealth related parameters $(\mathrm{PH}$, turbidity, chloride and sulphate) of bank-filtered water were assessed. Results showed that all parameters in bank filtrate (figure 7) are within the permissible limits recommended by EHCW and WHO.

- $\mathrm{pH}$ variation

Since water makes up more than two thirds of human body weight, the $\mathrm{pH}$ values of drinking water has effect on all body chemistry, health and disease. The $\mathrm{pH}$ values of the bank-filtered water collected from the abstraction wells varied from 7.3 to 8.2 with an average value of 7.8 , indicating slightly alkaline conditions. The alkaline nature of groundwater is possibly due to dissolution of calcium bicarbonates.

The $\mathrm{pH}$ values of bank-filtered water are within the permissible limits (6.5-8.5) recommended for drinking water by the Egyptian guideline and WHO standards. The obtained $\mathrm{pH}$ mean values (7.7) did not show much difference from those of the Nile raw-water (8.1), reflecting close association between them.

\section{- Turbidity}

The turbidity value of the bank-filtered water in the study sites ranged from 0.21 to 0.71 NTU (table 2 and figure 7 ). These values were less than the permissible limit, most likely due to the soil 


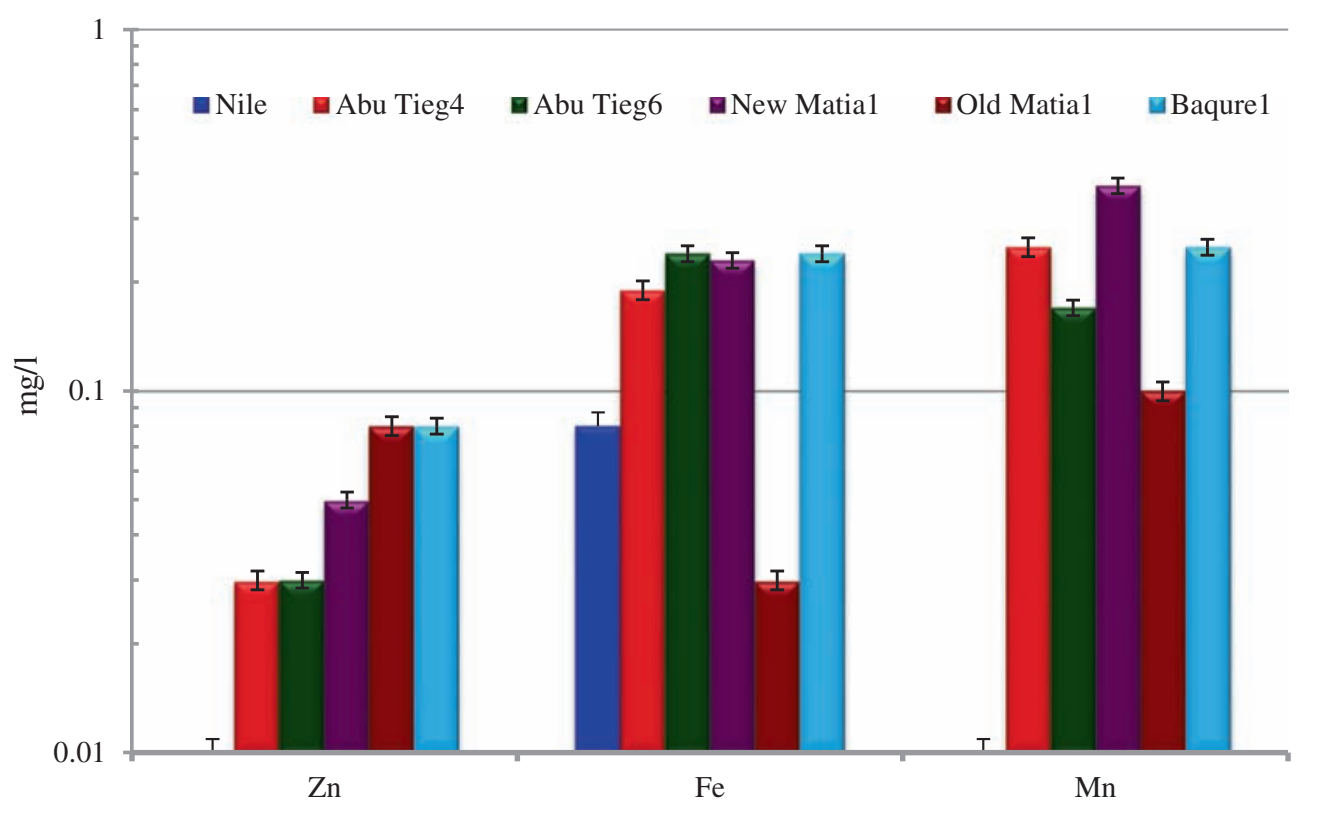

Figure 6. Comparison of heavy metal concentrations in the Nile and bank-filtrated water.

filtration effect of the underground passage and the properties of the riverbank sediments.

- Sulphate and chloride content

Sulphate and chloride concentrations in the bankfiltered water ranged between 10.1-42.1 and 7.3$67.1 \mathrm{mg} / \mathrm{l}$, respectively. They are higher than those detected in the Nile water and lower than those of groundwater, but they are still under the recommendation limits for both (400 and $250 \mathrm{mg} / \mathrm{l}$, respectively).

4.3.2.3 Other chemical parameters: The remaining parameters analyzed are the total organic carbon, total dissolved solids and total hardness (figure 8). TOC is important to detect early pollution events in drinking water supplies. Monitoring of TOC content in the finished water prior to distribution is also required to control disinfection by-products since they can be indicators of sewage contamination. The TOC contents recorded in the bankfiltered water ranged from 1.8 to $4.2 \mathrm{mg} / \mathrm{l}$ (table 2), with the minimum level observed at old El Matia1, while the maximum level was observed at Baqure2. These values are relatively lower than the observed concentrations in the Nile water.

- Total dissolved solids

TDS values in the bank-filtered water ranged between 227 and $621 \mathrm{mg} / \mathrm{l}$, the minimum level was observed at Abu Tieg5, while the maximum level was observed at old El Matia2 (figure 8 and table 1). These values are higher than those of the Nile water and lower than those of groundwater. The TDS concentrations in the waters tested were well below the permissible limits prescribed by $\mathrm{EHCW}$ and WHO for levels in drinking water $(1000 \mathrm{mg} / \mathrm{l})$.

\section{- Total hardness}

TH values recorded in the bank-filtered water ranges between 171.3 and $309 \mathrm{mg} / \mathrm{l}$, the minimum level was recorded at Abu Tieg5, while the maximum level was noticed at new El Matia wells. High TH values may be due to carbonate minerals dissolution and the alkaline nature of soils in the test sites. According to Sawyer and McCarty (1967) classification, all the bank-filtered water and Nile water samples fall under hard (150-300 mg/l) except new El Matia wells. The recorded TH values in all bank-filtered water samples (figure 8 and table 1) were higher than those of the Nile water and lower than those of groundwater, but they are below the permissible limit $(<500 \mathrm{mg} / \mathrm{l})$.

- Evaluating water saturation index

Corrosion control is an important aspect of safe drinking water supplies and chemical stability parameters of drinking water can improve their quality. To determine the corrosion potential in a recirculating water cooling systems through water distribution lines, Langelier SI as indicator of water aggressivity or scale forming was calculated (table 2). Calcium carbonate is considered as the most important ingredient in scale forming in cooling water pipes (Kahler 1944). Water quality parameters related to chemical stability SI include the following: $\mathrm{pH}$, temperature, alkalinity as $\mathrm{mg} / \mathrm{CaCO}_{3} \mathrm{mg} / \mathrm{l}$ as Ca, and TDS mg/l (Zia et al. 1999). According to Langelier (1936), the calculated values of LSI 


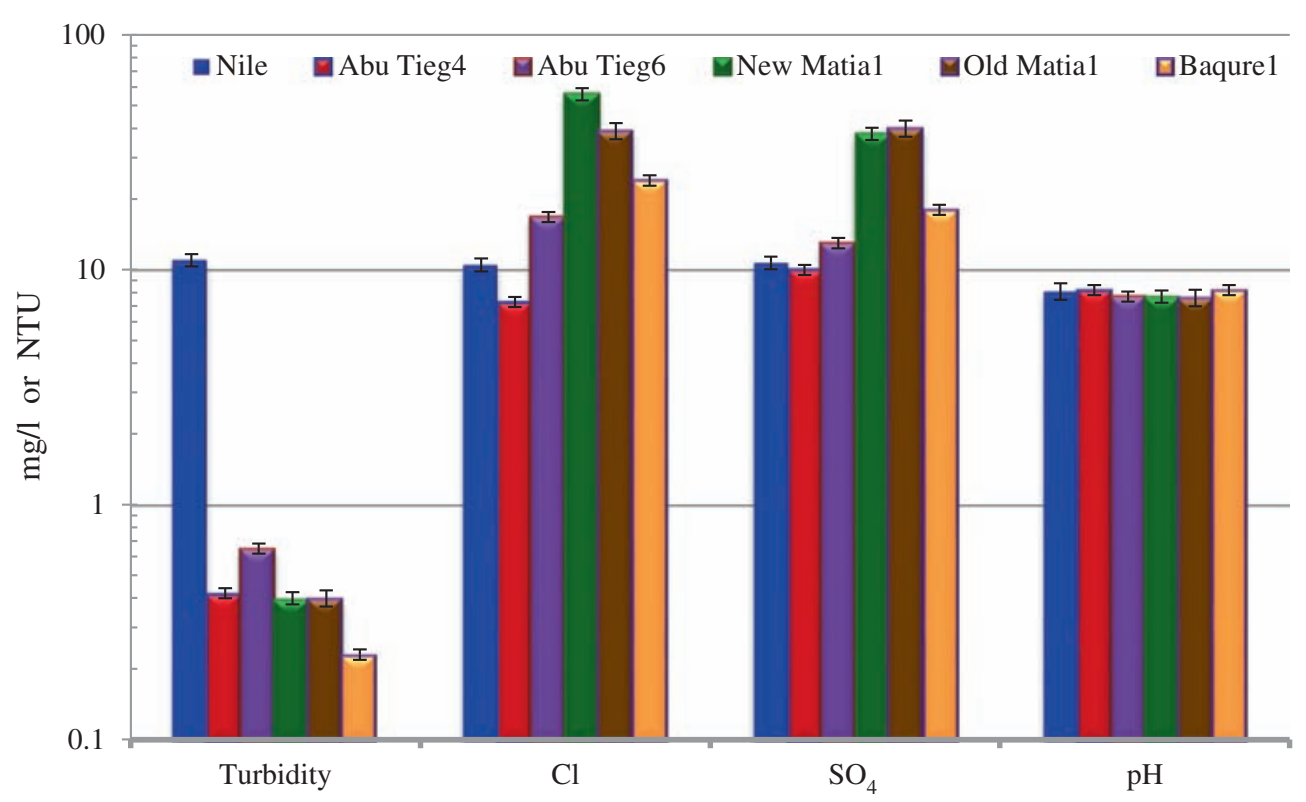

Figure 7. Comparison of non-health related parameters (turbidity, pH, chloride and sulphate in the Nile and bank-filtrated water.

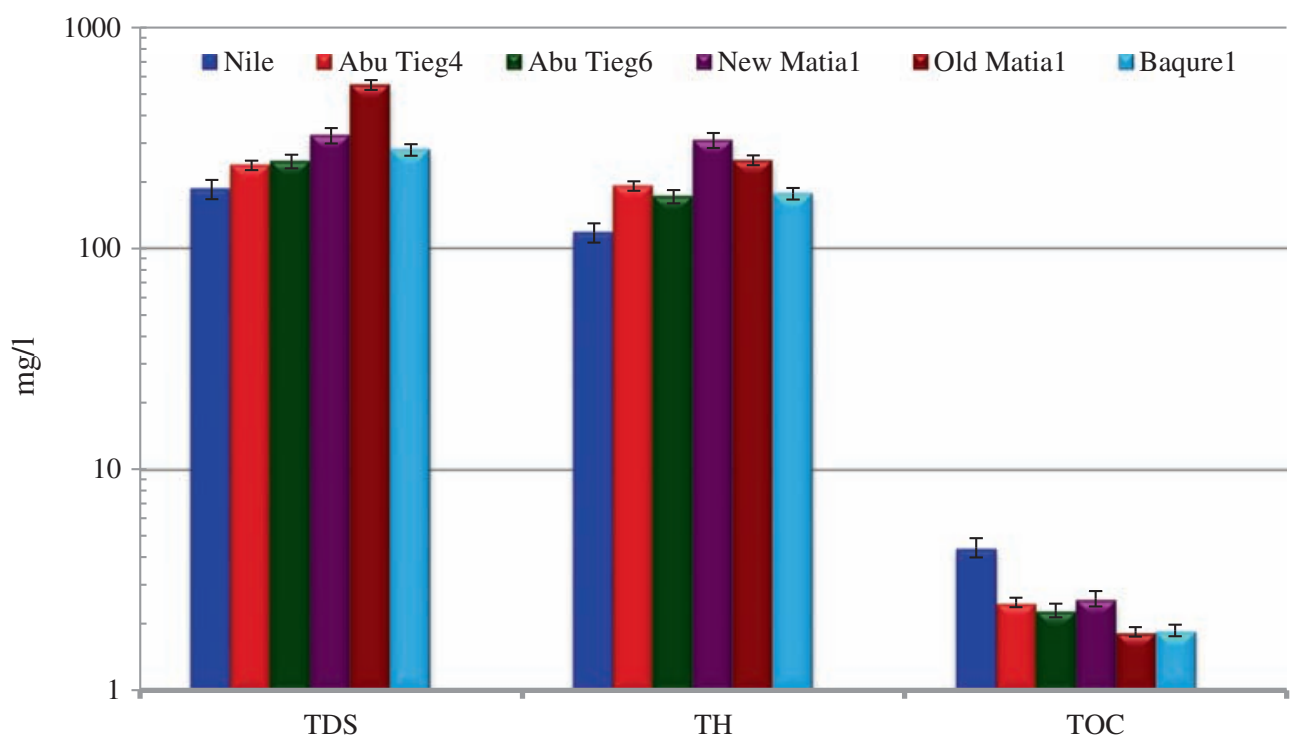

Figure 8. Comparison of TOC, TDS and TH in the Nile and bank-filtrated water.

(table 2) of bank-filtered water are positive and reflect non-corrosive or scale forming. They ranged from 0.046 to 0.79 indicating that water is supersaturated with respect to calcite.

- Evaluating water quality index

The following nine physico-chemical and bacteriologic parameters $(n=9)$ namely, turbidity, TDS, TH, $\mathrm{Na}, \mathrm{SO}_{4}, \mathrm{NO}_{3}, \mathrm{Fe}$, and total and faecal coliforms were used to calculate WQI to assess the suitability of bank-filtered water for drinking and domestic purposes. Calculated WQI values (table 1 ) showed that the lower value was found in bank-filtered water compared to both the Nile water and the groundwater, thus reflecting the effect of RBF as natural purification process. The quality of the bank-filtered water at Abu Tieg wells is in the range of excellent water with grade A (13-24.7) to good with grade B (30.7-40.3) at Baqure and El Matia sites mainly due to RBF process. The WQI values in Baqure and El Matia sites reflect the effect of iron remobilization and other constituents in the native groundwater. That means water in Abu Tieg production wells is protected with only very minor degree of threat or 
impairment. The Nile water and groundwater were classified as unsuitable with grade $\mathrm{E}(>100)$ and poor water quality with grade $\mathrm{C}(>56)$, respectively. The low WQI value for Nile water can be attributed to the high level of turbidity, total coliform and $E$. coli bacteria that exceeds the safe limit of drinking water standards, suggesting serious efforts are needed to reduce the contamination load and improve the quality of the Nile water.

\section{Summary and conclusion}

The study aims to investigate the potential impact of Nile water infiltration on groundwater quality in the Quaternary aquifer in Abu Tieg area applying RBF. The results showed that the physicochemical and microbiological characteristics of the bank-filtered water are different from those of the Nile water, due to RBF processes, particularly near the banks. Chloride concentrations and TDS values in bank-filtered water were used as tracers to determine the Nile water percentage contribution in the production wells. Findings showed that distance of RBF well from the Nile is a key rule controlling river water ratio and $\mathrm{RBF}$ removal efficiency of Nile contaminants. The estimated Nile water that infiltrates into the production wells reaches about $80 \%$ at Abu Tieg, $75 \%$ at new El Matia and 39\% at Baqure and old El Matia sites. Distance of 20$70 \mathrm{~m}$ between the Nile and production wells was found to be sufficient to receive high portion of Nile water and reduce/remove the pathogens and suspended load. Turbidity was recorded with high values in the Nile water than those in the bank-filtered water, and this probably is due to the filtration processes through RBF. The percentage removal of turbidity ranges from 93 to $98 \%$, depending on the properties of the riverbank sediments. Higher load of bacterial contamination from total and faecal coliform in the Nile revealed that the Nile water is under contamination from raw sewage discharges. Microbiological analysis showed that the load of total and faecal coliform bacterial contamination and algae in the Nile water was found to be heavy, while they were totally disappeared in the bankfiltered water. The nearly zero values of the microbial load and low turbidity value in bank-filtered water are good indicators for an effective removal of the RBF process through riverbank sediments. The TDS, TH and alkalinity are slightly increased in the bank-filtered water, but were still within the permissible limits. Moreover, due to the positive LSI values, the bank-filtered water is classified as noncorrosive, but scale-forming water. As expected, the WQI of the bank-filtered water is in the range of 'excellent' at Abu Tieg to 'good' at Baqure and
El Matia sites. Finally, the overall assessment of the physico-chemical and microbial quality parameters of bank-filtered water are reduced to be under the allowable standards of potable water in Egypt based on WHO and EHCW. Although, the results demonstrate the ability of RBF to reduce risk of THMs formed upon chlorination, lower coagulant dosages and sludge production in treatment plants, post-treatment may be needed to remove higher Mn concentrations in the RBF wells.

\section{Acknowledgements}

Authors would like to thank the staff of the central laboratory of Health Ministry in Cairo, Assiut Holding Company for drinking water and wastewater. Dr Scheytt, Mrs Pieper and Mr Yildiz from the Department of Applied Geosciences of TU Berlin, for their help. The authors would like to extend their sincere appreciation to the Deanship of Scientific Research at King Saud University for funding through research group (RGP-1437-012).

\section{References}

Abdalla F and Shamrukh M 2011 Riverbank filtration as a new treatment technology in Nile Valley: Case study, Abu Tieg City, Assiut, Egypt; In: Riverbank filtration for water security in desert countries (eds) Ray C and Shamrukh M, Springer, Dordrecht, The Netherlands, pp. 255-266.

Abdel-Lah A and Shamrukh M 2006 Riverbank filtration: A promise method for water supply from Nile, Egypt; In: Proceedings of 7th International Symposium on Water Supply Technology, Yokohama, Japan, November, pp. 385-395.

Adeogun A O 2012 Impact of industrial effluent on water quality and gill pathology of Clarias gariepinus from Alaro stream, Ibadan, southwest Nigeria; European J. Sci. Res. 76 83-94.

Akoteyon I, Omotayo A, Soladoye O and Olaoye H O 2011 Determination of water quality index and suitability of urban river for municipal water supply in Lagos, Nigeria; European J. Sci. Res. 54(2) 263-271.

American Public Health Association (APHA) 1998 Standard methods for the examination of water and wastewater, 17th edn; APHA, Washington, DC.

ATSDR 1992 The agency for toxic substances and disease registry; A Public Health Assessment Guidance Manual, US Dept. of Health and Human Services, Atlanta, Georgia.

Avvannavar S and Shrihari S 2008 Evaluation of water quality index for drinking purposes for river Netravathi, Mangalore; South India Environ. Monit. Assess. 143 279-290.

Balan I, Shivakumar M and Kumar P 2012 An assessment of groundwater quality using water quality index in Chennai, Tamil Nadu, India; Chronicles of Young Scientists 3(2) 146-150.

Bartak R, Grischek T, Ghodeif $\mathrm{K}$ and Wahaab R 2014 Shortcomings of the RBF pilot site in Dishna, 
Egypt; J. Hydrol. Eng., doi: 10.1061/(ASCE)HE.19435584.0001137.

Dawoud M and Ismail S 2013 Saturated and unsaturated River Nile/groundwater aquifer interaction systems in the Nile Valley, Egypt; Arabian J. Geosci. 6 21192130 .

Deininger R, Lee J, Ancheta A and Somana C 2002 Public health aspects of riverbank filtration; In: River bank filtration: Understanding contaminant biogeochemistry and pathogens removal (ed.) Ray C (The Netherlands: Kluwer Academic Publisher) Earth Environ. Sci., NATO Science Series 14 153-176.

Doussan C, Poitevin G, Ledoux E and Detay M 1997 Riverbank filtration: Modeling of the changes in water chemistry with emphasis on nitrogen species; J. Contam. Hydrol. 25 129-156.

Egyptian Higher Committee of Water (EHCW) 2007 Egyptian standards for drinking and domestic water according to the Act 27/1978 in regulating of the public water supplies; Egyptian Governmental Press, Egypt.

El Miligy E M 2004 Groundwater resources evaluation of Assiut area; Ph.D. thesis, Fac. Sci., Assiut University, Egypt.

Farrag A A 2005 The hydraulic and hydrogeological impacts of the Nile system on the groundwater in Upper Egypt, Assuit University; Bull. Environ. Res. 8 87-102.

Fleisher J M, Kay D, Wyer D and Godfree A F 1998 Estimates of the severity of illness associated with bathing in marine recreational waters contaminated with domestic sewage; Int. J. Epidemiol. 27 722-726.

Giannoulis N, Maipa V, Konstantinou I, Albanis T and Dimoliatis I 2005 Microbiological risk assessment of Agios Georgios source supplies in north western Greece based on faecal coliform determination and sanitary inspection survey; Chemosphere 58 1269-1276.

International Agency for Research on Cancer (IARC) 1991 Chlorinated drinking water; Chlorination by-products; Some other halogenated compounds; Cobalt and cobalt compounds; IARC Monographs on the Evaluation of Carcinogenic Risks to Humans, Lyon, France, 52 544p.

Ibrahim H A, Ebraheem A M, Abu El Ella E M, Bakheit A A and El Hussaini A H 1995 The study of groundwater resources along the plain of the River Nile (from Aswan to Assiut) using geoelectrical resistivity methods. Proceedings of the 1st inter. Conf.: The environment and development in Africa, 21-24 October, Assiut University, Egypt, pp. 273-300.

Kahler H I 1944 Once through and recirculation cooling water studies; Proceedings, Engineers Society Western Pcnna, pp. 39-62.

Kim S, Corapcioglu M and Kim D 2003 Effect of dissolved organic matter and bacteria on contaminant transport in riverbank filtration; J. Contam. Hydrol. 66 1-23.

Korany E A, Tempel R N, Gomaa M A and Mohamed R 2013 Detecting the roles of the physiochemical processes on groundwater evolution, Assiut area, Egypt - applications of hydrogeochemical and isotopic approaches; Egyptian J. Geol. 57 63-83.

Kuehn W and Mueller U 2000 Riverbank filtration: An overview; J. Am. Water Works Assoc. 92 60-69.

Langelier F 1936 The analytical control of anticorrosion water treatment; J. Am. Water Works Assoc. 28 15001521.

Macler A B and Merkel C J 2000 Current knowledge on groundwater microbial pathogens and their control; Hydrogeol. J. 8 29-40.

Mohod C and Dhote J 2013 Review of heavy metals in drinking water and their effect on human health; IJIRSET $\mathbf{2}$ 2992-2996.
Morris R, Naumova E, Levin R and Munasinghe L 1996 Temporal variation in drinking water turbidity and diagnosed gastroenteritis in Milwaukee; Am. J. Public Health $86237-239$.

Mousa S E, Attia F A and Abu ElFotouh A M 1994 Geological and hydrogeological study on the Quaternary aquifer in the Nile Valley between Assiut and Sohage Governorates; Egyptian Geol. J. 38 1-20.

Nieuwenhuijsen K, de Boer A, Spelten E and Sprangers M A et al. 2009 The role of neuropsychological functioning in cancer survivors' return to work one year after diagnosis; Psychooncology 18 589-597.

Pressman G, Richardson D, Speth F, Miltner J, Narotsky G, Hunter S, Rice E, Teuschler K, McDonald A, Parvez S, Krasner W, Weinberg S, McKague B, Parrett J, Bodin N, Chinn R, Lee T and Simmons E 2010 Concentration, chlorination, and chemical analysis of drinking water for disinfection byproduct mixtures health effects research: U.S. EPA's Four Lab Study; Environ. Sci. Technol. 44 7184-7192.

Ray C, Melin G and Linsky R B 2002 Riverbank Filtration: Improving Source Water Quality; Kluwer, The Netherlands.

Richardson R M, Sun D and Bullock M R 2007 Neurogenesis after traumatic brain injury; Neurosurgery Clinics of North America 18 169-181.xi.

Robertson W D, Cherry J A and Sudicky E A 1991 Groundwater contamination from two small septic systems on sand aquifers; Ground Water 29 82-92.

Said R 1981 The geological evolution of the River Nile; Springer-Verlag, New York, Heidelbeirg, Berlin.

Sawyer C and McCarty P 1967 Chemistry and Sanitary Engineers, 2nd edn; McCraw-Hill, New York, 518p.

Schmidt C K, Lange F T, Brauch H G and Kühn W 2003 Experiences with riverbank filtration and infiltration in Germany; DVGW-Water Technology Center, TZW, Germany.

Shamrukh M and Abdel-Wahab A 2008 Riverbank filtration for sustainable water supply: Application to a large-scale facility on the Nile River; Clean Technol. Environ. Policy 10(4) 351-358.

Shamrukh M and Abdel-Wahab A 2009 Water Pollution and Riverbank Filtration for Water Supply along River Nile, Egypt; NATO Advanced Research Workshop 'Riverbank Filtration for Water Security in Desert Countries', Luxor, Egypt, 24-27 October.

Shamrukh M and Abdel-Wahab A 2011 Water pollution and riverbank filtration for water supply along river Nile, Egypt; In: Riverbank filtration for water security in desert countries (eds) Ray $\mathrm{C}$ and Shamrukh M, Springer, Dordrecht, The Netherlands, pp. 255266.

Shehata A, Ali H and Wahba Z 2008 Distribution pattern of Nile water algae with reference to its treatability in drinking water; J. Appl. Sci. Res. 4(6) 722-730.

Seth R, Mohan M, Singh P, Singh R, Dobhal R, Singh K and Gupta S 2014 Water quality evaluation of Himalayan rivers of Kumaun region, Uttarakhand, India; Appl. Water Sci., doi: 10.1007/s13201-014-0213-7.

Stuyfzand P J 1998 Fate of pollutants during artificial recharge and bank filtration in the Netherlands; In: Artificial Recharge of Groundwater (ed.) Peters J H, Water Research Association, Medmenham, England, pp. 119-125.

Todd D 1980 Ground Water Hydrology, 2nd edn; Wiley, New York.

Ozoko D 2015 Corrosion potentials of natural waters in Abakaliki, Ebonyi State, Nigeria; J. Natural Sci. Res. 5(9) 108-114. 
Valiela I, Collins G, Kremer J, Lajtha K, Geist M, Seely B, Brawley J and Sham C H 1997 Nitrogen loading from coastal watersheds to receiving estuaries: new method and application; Ecol. Appl. 7(2) 358380 .

van der Kooij D, Groennou J T, Kruithof J C, Noordam P C, Noordsij A, Stuyfzand P J and van der Gaag M A 1985 Water quality aspects of river bank filtration in the Netherlands; Water Supply 3 41-50.
Wilhelm S R, Schiff S L and Cherry J A 1994b Biogeochemical evolution of domestic waste water in septic systems: 1. Conceptual model; Ground Water 32 905-916.

World Health Organization (WHO) 2008 Guidelines for Drinking-water Quality; 3rd edn, Incorporating the first and second Addenda, Volume 1, Geneva.

Zia M, Iqbal M, Nawaz H and Samin G 1999 Langelier calcium carbonate saturometry determination by table values; Int. J. Agri. Biol. 1 353-355.

MS received 2 November 2015; revised 16 March 2016; accepted 30 August 2016

Corresponding editor: RAJIB MAITY 